\title{
Anti-Angiogenic Property of Free Human Oligosaccharides
}

 \\ 1 Department of Korean Medicine, School of Korean Medicine, Pusan National University, \\ Yangsan 50612, Gyeongsangnam-do, Korea; corona1814@pusan.ac.kr (B.B.); haeunhamin@pusan.ac.kr (H.K.) \\ 2 Korean Medical Research Center for Healthy Aging, Pusan National University, \\ Yangsan 50612, Gyeongsangnam-do, Korea; rin8998@pusan.ac.kr \\ 3 GI Innovation, Inc., A-1116, Tera Tower, Songpa-gu, Seoul 05855, Korea; youngjun.koh@gi-innovation.com \\ * Correspondence: Dr.NowOrNever@pusan.ac.kr (S.-J.B.); hagis@pusan.ac.kr (K.-T.H.); \\ Tel.: +82-51-510-8434 (S.-J.B.); +82-51-510-8464 (K.-T.H.) \\ + These authors contributed equally to this study.
}

check for updates

Citation: Bae, B.; Kim, H.; Park, H.; Koh, Y.J.; Bae, S.-J.; Ha, K.-T. Anti-Angiogenic Property of Free Human Oligosaccharides. Biomolecules 2021, 11, 775. https:// doi.org/10.3390/biom11060775

Academic Editor: Tamás Röszer

Received: 27 April 2021

Accepted: 19 May 2021

Published: 21 May 2021

Publisher's Note: MDPI stays neutral with regard to jurisdictional claims in published maps and institutional affiliations.

Copyright: (c) 2021 by the authors. Licensee MDPI, Basel, Switzerland. This article is an open access article distributed under the terms and conditions of the Creative Commons Attribution (CC BY) license (https:// creativecommons.org/licenses/by/ $4.0 /)$.

\begin{abstract}
Angiogenesis, a fundamental process in human physiology and pathology, has attracted considerable attention owing to its potential as a therapeutic strategy. Vascular endothelial growth factor (VEGF) and its receptor (VEGFR) are deemed major mediators of angiogenesis. To date, inhibition of the VEGF-A/VEGFR-2 axis has been an effective strategy employed in the development of anticancer drugs. However, some limitations, such as low efficacy and side effects, need to be addressed. Several drug candidates have been discovered, including small molecule compounds, recombinant proteins, and oligosaccharides. In this review, we focus on human oligosaccharides as modulators of angiogenesis. In particular, sialylated human milk oligosaccharides (HMOs) play a significant role in the inhibition of VEGFR-2-mediated angiogenesis. We discuss the structural features concerning the interaction between sialylated HMOs and VEGFR-2 as a molecular mechanism of anti-angiogenesis modulation and its effectiveness in vivo experiments. In the current state, extensive clinical trials are required to develop a novel VEGFR-2 inhibitor from sialylated HMOs.
\end{abstract}

Keywords: human milk oligosaccharides; sialyllactose; angiogenesis; VEGFR-2; inhibitor

\section{Introduction}

Milk oligosaccharides are milk components with diverse biological functions [1]. In particular, human milk has been utilized as a medicinal food due to its nutritional composition and non-nutritive bioactive factors [2]. Breast milk, which is ideal for infants, contains numerous complex ingredients, including proteins, lipids, carbohydrates, minerals, and other minor nutrients [3]. Among human milk components in colostrum, oligosaccharides are the third most abundant, present at concentrations of up to $20-25 \mathrm{~g} / \mathrm{L}$ [4]. However, newborn babies lack enzymes that digest complex milk oligosaccharides. Thus, the precise physiological role of milk oligosaccharides remained elusive until the 1960s [4,5]. However, pioneering studies in the early 20th century have discovered that the carbohydrate fraction of human milk contains growth-promoting factors for Lactobacillus bifidus [4]. Currently, accumulated data suggest that human milk oligosaccharides (HMOs) are prebiotics, as well as modulators of the intestinal mucosal and systemic immune response $[4,6]$.

All HMOs contain five different monosaccharides, including $D$-glucose, $D$-galactose, $L$-fucose, $N$-acetylglucosamine and $N$-acetylneuraminic acid [3]. Approximately 150 different types of oligosaccharides have been identified in human milk, with all possessing a lactose unit at the reducing end [3,5]. Typically, HMOs are classified as neutral and acidic oligosaccharides based on the respective presence or absence of negatively charged $\mathrm{N}$-acetylneuraminic acid, that is, sialic acid [6]. In several aspects, the biological activities of acidic HMOs tend to differ from those of neutral HMOs [7,8]. Naturally occurring free oligosaccharides harboring sialic acid have been found in both plasma and urine in healthy men and women, especially in pregnant and lactating women [9-11]. Free sialylated 
oligosaccharides frequently present in human milk inhibit the adhesion of immune cells, cholera toxin, and influenza virus with endothelial or epithelial cells [12-14]. Moreover, the sialic acid-containing portion of HMOs is essential for early neurodevelopment and cognition $[15,16]$.

In the present review, we focused on the modulation of angiogenesis via humanderived oligosaccharides, especially free sialylated oligosaccharides, to ameliorate diseases associated with excessive angiogenesis.

\section{Angiogenesis in Human Health and Disease}

\subsection{Physiological and Pathological Angiogenesis}

In vertebrates, the vascular system plays a crucial role in organ homeostasis by transporting oxygen and nutrients [17]. Closed blood vessel systems, like those in vertebrates, first appeared in their common ancestor over 500 million years ago to optimize flow dynamics and barrier function [18]. Reportedly, metabolic requirements for oxygen and nutrients induce new blood vessel formation from the existing ones, a process termed angiogenesis [19]. Angiogenesis was initially considered as a physiological process for maintaining metabolic homeostasis in the field of developmental biology [20]. Inevitably, new blood vessel formation plays a critical role in early development, tissue growth and wound healing [19]. Furthermore, female reproductive physiology, including oocytogenesis, embryo implantation and the menstruation cycle, are regulated by angiogenesis (Figure 1) [21].

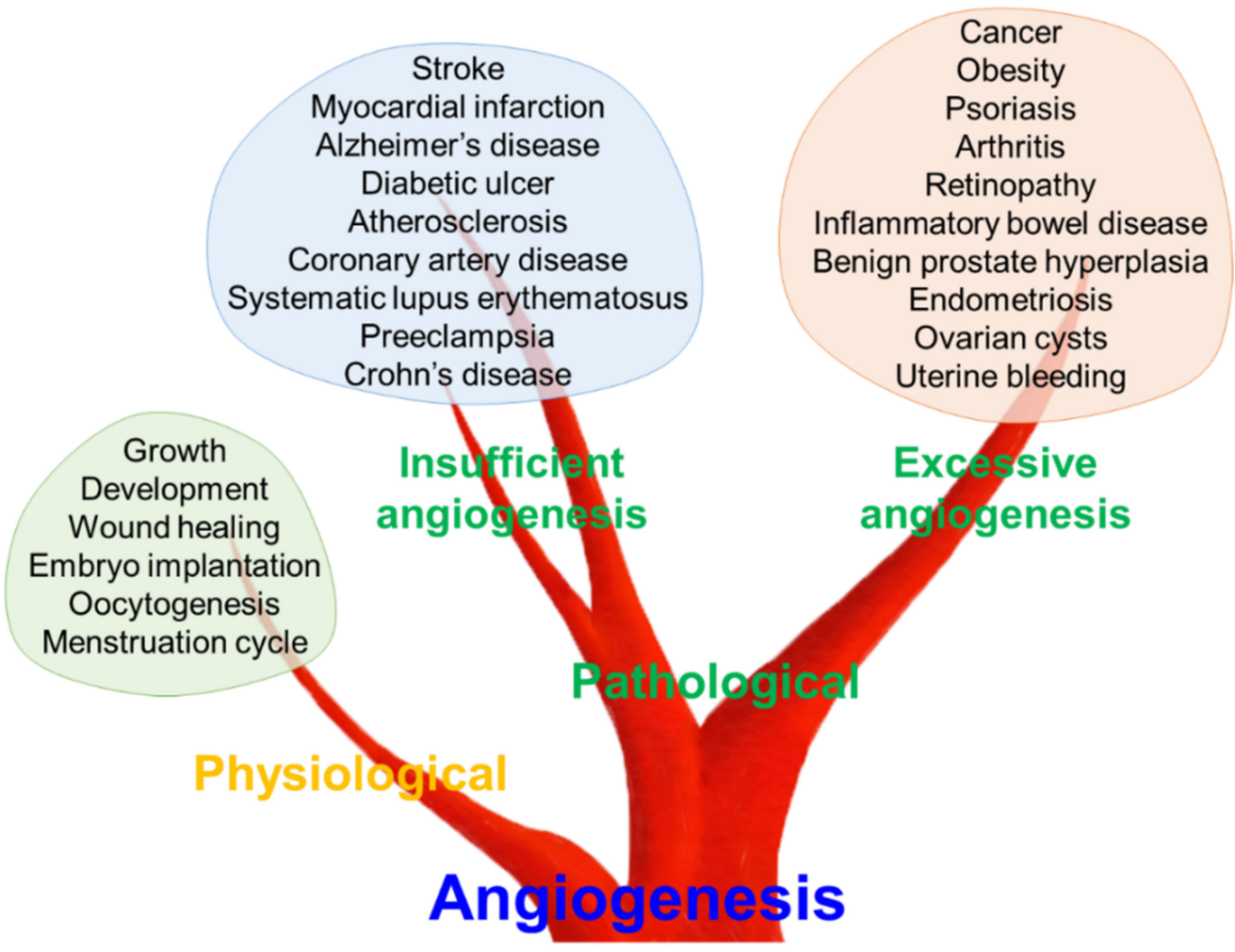

Figure 1. Role of angiogenesis in physiological and pathological conditions. Angiogenesis is a fundamental process in human physiology and pathology. Dysregulated angiogenesis, both insufficient and excessive angiogenesis, can lead to various pathological conditions.

Conversely, angiogenesis could be employed as a therapeutic target for treating pathological conditions characterized by either insufficient vascularization or excessive vasculature $[22,23]$. Tumor-derived factors to promote neovascularization were first postulated in the late 1930s [23]. In 1971, Folkman [24] suggested that inhibition of angiogenesis might have potential therapeutic implications in cancer therapy. These pioneering studies 
have highlighted the concept that angiogenesis is an important biological process and therapeutic target in diverse diseases, including cancer [25]. The excessive growth of new vessels can aggravate diverse disorders, ranging from cancer and obesity to retinopathy, such as age-related macular degeneration [22,26]. Psoriasis, arthritis, inflammatory bowel disease, benign prostate hyperplasia, endometriosis, ovarian cysts, and uterine bleeding also have been reported to have a mutual correlation with excessive angiogenesis $[22,27,28]$. In contrast, insufficient angiogenesis can contribute to various diseases, such as stroke, myocardial infarction, diabetic ulcers, atherosclerosis, coronary artery disease, systematic lupus erythematosus, preeclampsia, Alzheimer's disease, and Crohn's disease [22,26,29]. Thus, balanced regulation of the angiogenic process might be a key factor for maintaining human health and preventing or treating numerous diseases.

\subsection{Vascular Endothelial Cell Growth Factors (VEGFs) and Their Receptors (VEGFRs) as Therapeutic Targets for Pathological Angiogenesis}

Angiogenesis involves the formation and maintenance of new blood vessels via the cooperation of multiple cells in vascular networks, including vascular endothelial cells, their progenitor cells and pericytes [30,31]. Based on the dynamic interplay between these cells, new blood vessel-like structures are formed via multistep processes, such as sprouting, tip cell migration and tube formation [22,32]. These processes are regulated by signaling between endothelial cells and the perivascular cell layer by secreting growth factors, direct cell-cell interaction, and extracellular matrix production [31-33]. Among the secretory growth factors that regulate angiogenesis, VEGFs are the most important, as they play key roles in multiple steps of neovascular formation (Figure 2) [31,34]. Thus, the axis of VEGFs and their receptors (VEGFRs) has been considered a therapeutic target for modulating angiogenesis since the beginning of anti-angiogenic studies [24,35].

In mammals, the VEGF family consists of five members, including VEGF-A, VEGF$B$, VEGF-C, VEGF-D, and placental growth factor (PLGF). These ligands bind to their respective receptors (VEGFRs), which belong to the type IV receptor tyrosine kinase (RTK) family and are composed of three members, VEGFR-1, VEGFR-2, and VEGFR-3 [36,37]. Once the ligand binds to the receptor, homo- or hetero-dimeric interactions of VEGFRs initiate the autophosphorylation of intracellular tyrosine residues, as well as downstream signaling pathways responsible for the proliferation, migration and remodeling of the vascular endothelial cells $[34,36]$. Among them, VEGFR-1 and VEGFR-2 play critical roles in physiological and pathological angiogenesis. In blood vascular endothelial cells, angiogenesis is predominantly mediated via VEGFR-2 activation [38]. VEGF-A, VEGF-B, and PLGF are high-affinity ligands of VEGFR-1, but the kinase activity of VEGFR-1 is relatively weak for the progression of the angiogenesis [39]. In some cancers, VEGF-C sustains VEGFR-2 activation by binding to VEGFR-2 even when inhibiting VEGF-A [40,41]. VEGF-C and VEGF-D stimulate VEGFR-3 activation, which plays an indispensable role in both angiogenesis and lymphangiogenesis [42]. Furthermore, the cooperative signaling between VEGFR-2 and -3 is involved in forming new lymphatic vessels (Figure 3) [43]. 




Figure 2. Molecular mechanism of angiogenesis and multicellular interaction during new vessel development. In response to stimulators such as VEGFs, vascular endothelial cells sprout from the basement membrane and migrate to the site of new vessel formation. The formation of tip and stalk cells is regulated by the VEGF-DLL4/NOTCH signaling pathway. The other stimulating molecules, such as PDGF, EGF, FGF, BMPs, and TGF- $\beta$, also cooperate to regulate pericytes and tip cells. ALK1/5, actin receptor-like kinase 1/5; BMP, bone morphogenic protein (yellow dots); DLL4, delta-like protein 4; EGF, epidermal growth factor (black dot); EGFR, epidermal growth factor receptor; FGF, fibroblast growth factor (gray dot); FGFR, fibroblast growth factor receptor; NICD, intracellular domain of the notch protein; PDGF, platelet-derived growth factor (green dot); PDGFR, platelet-derived growth factor receptor; TGF- $\beta$, transforming growth factor- $\beta$ (dark yellow dots); VEGF-A, vascular endothelial cell growth factor A (orange dots); VEGF-C, vascular endothelial cell growth factor C (red dots); VEGFR, vascular endothelial cell growth factor receptor.

Therefore, considerable efforts to inhibit VEGFR-2 activation have been made to suppress angiogenesis as pathogenic angiogenesis is predominantly mediated by the VEGFA/VEGFR-2 axis [44]. Several strategies for suppressing excessive angiogenesis have been exploited, including neutralizing monoclonal antibodies, VEGF-trapping recombinant proteins and small molecule tyrosine kinase inhibitors [34,35,45]. Among them, neutralizing VEGF-A using the anti-VEGF-A monoclonal antibody, bevacizumab (brand name Avastin), has been inhibiting angiogenesis most successfully in clinical settings. It has been approved as a conventional treatment for several cancers, such as colorectal cancer, lung cancer, glioblastoma, renal cell carcinoma, and age-related macular degeneration [46-48]. However, the use of bevacizumab has revealed several limitations, such as high cost, no effect on overall survival in a few cancer cases, and adverse effects on coronary and peripheral artery disease $[49,50]$. Accordingly, several researchers have focused on developing an effective and safe anti-angiogenic agent from small molecule compounds [34,35]. The majority of small molecule anti-angiogenic agents target the tyrosine kinase activity of VEGFRs [51,52]. However, these chemical inhibitors for tyrosine kinases have been unsuccessful owing to their low specificity and mutation-induced drug resistance [51,53]. As the extracellular ligand-binding region of RTKs is markedly diverse in terms of the protein structure, they are considered more suitable for developing specific inhibitors [54,55]. Accordingly, several investigations reported that interactions between VEGF-A and its receptor could be intercepted by employing recombinant peptides and peptidomimetic chemicals [56-58]. 


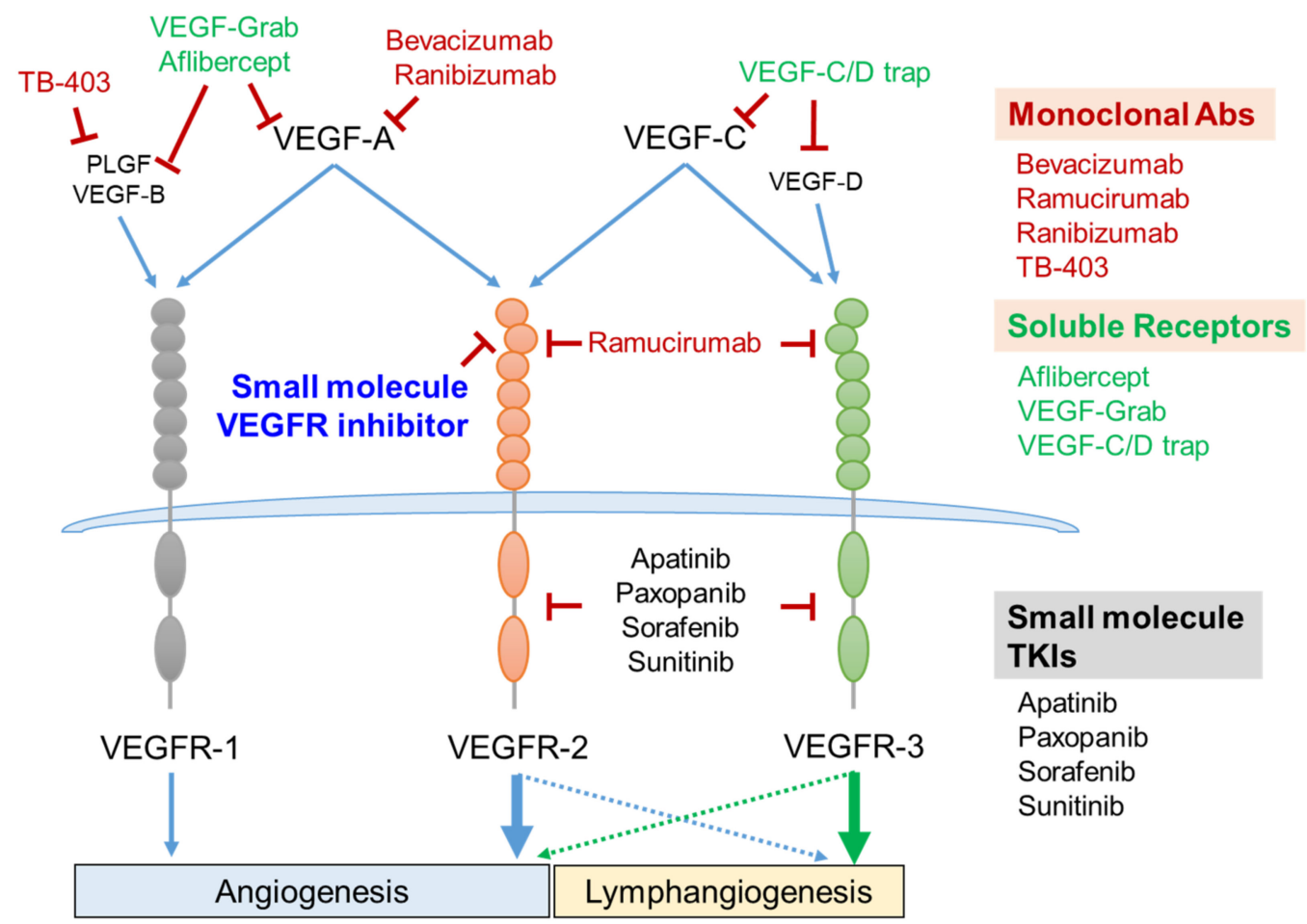

Figure 3. VEGF/VEGFR axis as a therapeutic target and its intervention strategies. Five members of the VEGF family are composed of VEGF-A, VEGF-B, VEGF-C, VEGF-D, and PLGF. VEGF-A binds to both VEGFR-1 and VEGFR-2. VEGF-C binds to both VEGFR-2 and VEGFR-3. VEGF-B and PLGF bind to VEGFR-1, and VEGF-D binds to VEGFR-3. VEGFR-1- and VEGFR-2-mediated signaling cascades regulate vascular angiogenesis. VEGFR-3 activation is essential for lymphangiogenesis (green arrow). VEGFR-2 cooperatively activates lymphangiogenesis with VEGFR-3 (blue dashed arrow), and VEGFR-3 also slightly enhances the vessel angiogenesis (green dashed arrow). Several monoclonal antibodies and recombinant soluble receptors consisting of the extracellular domains of VEGFRs have been successfully developed as therapeutic anti-angiogenic agents. Small molecules targeting the intracellular tyrosine kinase domain or extracellular VEGF-binding domain are under development as novel strategies for inhibiting angiogenesis. Abs, antibodies; PLGF, placenta growth factor; TKIs, tyrosine kinase inhibitors; VEGF, vascular endothelial cell growth factor; VEGFR, vascular endothelial cell growth factor receptor.

\section{Human Milk Oligosaccharides and Angiogenesis}

\subsection{Oligosaccharides and Angiogenesis}

Several different types of oligosaccharide chains exist in mammals as bound to proteins, lipids, or repeating sugar units $[59,60]$. Oligosaccharide-linked proteins or lipids, that is, glycoproteins or glycolipids, respectively, are mainly located on the cell surface and have distinct biological functions, including mediation of viral/bacterial infection, immune response, cell-cell interaction and cancer progression [61]. Additionally, numerous ligand-receptor interactions might be regulated by the glycosylation status, especially those involving $\mathrm{G}$ protein-coupled receptors and growth factor receptors [61-63]. It is well known that ligand binding and trafficking of epidermal growth factor receptor (EGFR), fibroblast growth factor-1 and VEGFR-2, the most crucial RTKs in cancer-associated angiogenesis, are affected by site-specific $N$-glycosylation [64-66]. Conversely, in the present review, we focused on the pro- or anti-angiogenic roles of unbound oligosaccharides to determine their potential as therapeutic modulators of angiogenesis.

As shown in Table 1, different types of oligosaccharides have pivotal roles in angiogenesis. Hyaluronan types, including their fragments, generally promote angiogenic processes [67-79]. Several hyaluronan receptors, including CD44, receptor for hyaluronanmediated motility, LYVE-1 and CD31 [69,70,72,73,76], and their downstream signaling 
molecules, such as protein kinase C, Src, extracellular signal-regulated kinase (ERK), transforming growth factor- $\beta$ and Janus kinase/signal transducer and activator of transcription $[75,77,78]$, are involved in hyaluronan-stimulated angiogenesis. Two studies reported that high molecular weight hyaluronan inhibits angiogenesis, whereas small molecular weight hyaluronan promotes angiogenesis $[80,81]$. Heparin oligosaccharides, such as heparin and their fragments combined with corticosteroid and heparin-like glycosaminoglycans, caused inhibitory effects on angiogenesis [80,82]. However, heparin itself promotes angiogenesis by binding to $\alpha 2$-macroglobulin, thus decreasing the inhibitory effect of $\alpha 2$-macroglobulin on VEGF [83]. Furthermore, fucosylated oligosaccharides typically promote angiogenesis by interacting with FGF-2 and galectin- 12 and through the secretion of basic fibroblast growth factor (bFGF) and VEGF [84-86]. However, fucosylated glycosaminoglycan and its derivatives suppress angiogenesis by inhibiting heparanase [87].

Table 1. Summary of studies investigating the effects of oligosaccharides on angiogenesis.

\begin{tabular}{|c|c|c|c|c|c|}
\hline Compound & $\begin{array}{l}\text { Reference } \\
\text { (PMID) }\end{array}$ & Exam & Molecular Target & $\begin{array}{c}\text { Effect on } \\
\text { Angiogenesis }\end{array}$ & Disease Model \\
\hline \multirow{3}{*}{$\begin{array}{l}\text { Heparin, heparan sulfate, or their } \\
\text { fragments }\end{array}$} & 7681826 & in vitro & «2-Macroglobulin & Promotion & N.D. ${ }^{(1)}$ \\
\hline & 3746342 & $\begin{array}{l}\text { in vitro, } \\
\text { in vivo }\end{array}$ & $\begin{array}{l}\text { Growth of cerebral } \\
\text { microvessel } \\
\text { endothelial cell }\end{array}$ & Inhibition & N.D. ${ }^{(1)}$ \\
\hline & 14517393 & in vitro & FGF & Inhibition & N.D. ${ }^{(1)}$ \\
\hline \multirow{14}{*}{$\begin{array}{l}\text { Hyaluronan, hyaluronic acid, or } \\
\text { their fragments }\end{array}$} & 2408340 & in vitro & N.D. ${ }^{(1)}$ & Promote & N.D. ${ }^{(1)}$ \\
\hline & 2472284 & in vitro & $\begin{array}{l}\text { Endothelial cell } \\
\text { proliferation }\end{array}$ & $\begin{array}{l}\text { Promotion or } \\
\text { inhibition }(2)\end{array}$ & N.D. ${ }^{(1)}$ \\
\hline & 1384133 & in vitro & N.D. ${ }^{(1)}$ & $\begin{array}{l}\text { Promotion or } \\
\text { inhibition }(2)\end{array}$ & N.D. ${ }^{(1)}$ \\
\hline & 8647630 & in vitro & $\mathrm{CD} 44$ & Promotion & N.D. ${ }^{(1)}$ \\
\hline & 7543630 & in vivo & N.D. ${ }^{(1)}$ & Promotion & $\begin{array}{l}\text { Skin wound } \\
\text { healing }\end{array}$ \\
\hline & 18544273 & in vitro & $\begin{array}{l}\text { RHAMM (receptor for } \\
\text { hyaluronan mediated } \\
\text { motility) }\end{array}$ & Promotion & $\begin{array}{l}\text { Skin wound } \\
\text { healing }\end{array}$ \\
\hline & 12194965 & in vitro & $P K C \alpha,-\beta 1,-\beta 2,-\varepsilon$ & Promotion & $\begin{array}{l}\text { Skin wound } \\
\text { healing }\end{array}$ \\
\hline & 19724912 & in vitro & CD44 and RHAMM & Promotion & Wound healing \\
\hline & 19913615 & in vivo & $\begin{array}{c}\text { LYVE-1 (lymphatic } \\
\text { vessel endothelial } \\
\text { hyaluronan receptor 1) } \\
\text { and CD31 }\end{array}$ & Promotion & $\begin{array}{l}\text { Skin wound } \\
\text { healing }\end{array}$ \\
\hline & 16544303 & in vitro & $\begin{array}{l}\text { Endothelial cell } \\
\text { proliferation }\end{array}$ & Promotion & Wound healing \\
\hline & 27588388 & in vivo & $\begin{array}{c}\text { Phosphorylation of Src } \\
\text { and ERK } \\
\text { TGF- } \beta \text { expression }\end{array}$ & Promotion & Diabetic wound \\
\hline & 31037151 & in vivo & $\begin{array}{c}\text { macrophage M2 } \\
\text { polarization (MAPK, } \\
\text { JAK/STAT pathway) }\end{array}$ & Promotion & $\begin{array}{l}\text { Myocardial } \\
\text { infarction }\end{array}$ \\
\hline & 26917404 & $\begin{array}{l}\text { in vitro, } \\
\text { in vivo }\end{array}$ & CD44 & Promotion & N.D. ${ }^{(1)}$ \\
\hline & 19720068 & in vitro & VEGF (mRNA level) & Promotion & N.D. ${ }^{(1)}$ \\
\hline
\end{tabular}


Table 1. Cont.

\begin{tabular}{|c|c|c|c|c|c|c|}
\hline \multicolumn{2}{|c|}{ Compound } & $\begin{array}{l}\text { Reference } \\
\text { (PMID) }\end{array}$ & Exam & Molecular Target & $\begin{array}{c}\text { Effect on } \\
\text { Angiogenesis }\end{array}$ & Disease Model \\
\hline \multicolumn{2}{|c|}{ Lacto-N-Neotetraose ${ }^{(3)}$} & 31969618 & $\begin{array}{l}\text { in vitro, } \\
\text { in vivo }\end{array}$ & Th2 immune response & Promotion & $\begin{array}{l}\text { Skin wound } \\
\text { healing }\end{array}$ \\
\hline \multirow{3}{*}{$\begin{array}{l}\text { Sialylated } \\
\text { oligosaccha- } \\
\text { rides }\end{array}$} & $\begin{array}{l}6 ' \text {-sialylgalactose, } \\
3^{\prime} \text {-sialylgalactose }\end{array}$ & 31604908 & $\begin{array}{l}\text { in vitro, } \\
\text { in vivo }\end{array}$ & VEGF receptor 2 & Inhibition & $\begin{array}{l}\text { Cancer and } \\
\text { retinopathy }\end{array}$ \\
\hline & $\begin{array}{c}6^{\prime} \text {-sialyllactose, } \\
3^{\prime} \text {-sialyllactose }\end{array}$ & 28938544 & $\begin{array}{l}\text { in vitro, } \\
\text { in vivo }\end{array}$ & VEGF receptor 2 & Inhibition & Cancer \\
\hline & $6^{\prime}$-sialyllactose ${ }^{(3)}$ & 31383249 & $\begin{array}{l}\text { in vitro, } \\
\text { in vivo }\end{array}$ & VEGF receptor 2 & Inhibition & $\begin{array}{c}\text { Benign } \\
\text { prostatic } \\
\text { hyperplasia }\end{array}$ \\
\hline \multirow{4}{*}{$\begin{array}{l}\text { Fucosylated } \\
\text { oligosaccha- } \\
\text { rides }\end{array}$} & $\begin{array}{c}\text { Fucosylated } \\
\text { glycosaminoglycan }\end{array}$ & 33667689 & $\begin{array}{l}\text { in vitro, } \\
\text { in vivo }\end{array}$ & Heparanase & Inhibition & Cancer \\
\hline & $\begin{array}{c}\text { Fucosylated } \\
\text { chondroitin sulfate }\end{array}$ & 12496356 & $\begin{array}{l}\text { in vitro, } \\
\text { in vivo }\end{array}$ & FGF-2 & Promotion & $\begin{array}{l}\text { Ischemia and } \\
\text { thrombosis }\end{array}$ \\
\hline & $\begin{array}{l}3^{\prime} \text {-fucosylated } \\
\text { glycans }^{(3)}\end{array}$ & 31914594 & $\begin{array}{l}\text { in vitro, } \\
\text { in vivo }\end{array}$ & Galectin-12 & Promotion & $\begin{array}{l}\text { Adipose } \\
\text { metabolic } \\
\text { disorder }\end{array}$ \\
\hline & $\begin{array}{c}2^{\prime} \text {-fucosyl lactose } \\
(\mathrm{H}-2 \mathrm{~g})\end{array}$ & 15498849 & $\begin{array}{l}\text { in vitro, } \\
\text { in vivo }\end{array}$ & $\begin{array}{c}\text { Secretion of bFGF and } \\
\text { VEGF }\end{array}$ & Promotion & N.D. ${ }^{(1)}$ \\
\hline
\end{tabular}

(1) N.D.: not determined. (2) Promoted by low molecular weight hyaluronan and inhibited by high molecular weight hyaluronan.

(3) Ingredients of human milk. ERK, extracellular signal-regulated kinase; FGF-2, fibroblast growth factor; TGF- $\beta$, Transforming growth factor-beta; VEGF, vascular endothelial growth factor.

Among the oligosaccharides listed in Table 1 , only some, including lacto- $N$-neotetraose (LNnT), fucosylated glycans, and sialylated oligosaccharides, are classified as HMOs. Especially, LNnT, a linear chain of a tetrasaccharide composed of galactose [88], $\mathrm{N}$-acetylglucosamine and lactose, is reportedly a prebiotic that promotes the growth of Bifidobacterium longnum, especially the subspecies infantis $[89,90]$. Helminths-derived LNnT showed an immunosuppressive effect by augmenting $\mathrm{Gr}^{+}{ }^{+}$cells and inhibiting naïve $\mathrm{CD}^{+}$cells [91]. Recently, it was reported that $\mathrm{LNnT}$ accelerates the wound healing process by inducing angiogenesis and promoting type 2 immune responses [92,93]. Approximately $50-80 \%$ of HMOs are fucosylated with fucose linked in $\alpha 1-2, \alpha 1-3$ or $\alpha 1-4$ linkages to galactose, glucose, or $\mathrm{N}$-acetylglucosamine [2], and have demonstrated beneficial effects on reducing Campylobacter jejuni-associated diarrhea in a human translational study [94]. Core fucosylated free oligosaccharides derived from maternal milk $N$-glycosylated proteins activate B cells via B cell receptor-mediated downstream signaling [95]. Several studies have revealed that fucosyltransferases and fucosylated proteins play positive roles in angiogenesis via the activation of fibroblasts, vascular endothelial cells, and endothelial progenitor cells [96-98]. In addition, the fucosylated glycans increase angiogenesis by interacting with galectin-12 or releasing angiogenic bFGF and VEGF $[84,86]$.

\subsection{Roles of Sialylated HMOs in Pathologic Angiogenesis}

Several cell-surface proteins, such as mucins, ion channels, receptors, and adhesion molecules, are highly glycosylated with terminal sialic acid residues [61]. Numerous studies have revealed that cell surface glycosylated molecules bound to growth factor receptors regulate their proangiogenic function [99-101]. $N$-glycosylation, especially that of terminal sialic acid residues, regulates ligand-dependent activation of VEGFR-2 [102]. Not only proteins, a sialylated glycosphingolipid, GM3, reportedly exhibits an anti-angiogenic effect by inhibiting VEGFR2 activation [103,104]. Although two review papers have discussed the role of glycosylation as a novel therapeutic target for diseases associated with excessive angiogenesis $[105,106]$, none of them described the exact functions of sialylated HMOs 
in angiogenesis. In 2004, Rudloff et al. [107] demonstrated that sialylated HMOs have an anti-angiogenic effect on bovine vascular endothelial cells by employing an in vitro tube formation assay. However, the study failed to identify the precise components of acidic HMOs and the mechanism underlying their anti-angiogenic effects.

In this regard, our group recently revealed the specific components of anti-angiogenic acidic HMOs and their underlying mechanisms. Unlike other HMOs summarized in Table 1, we identified that $3^{\prime}$ - and 6 -sialyllactose inhibited angiogenesis (Figure 4) $[108,109]$. However, their analogs, $3^{\prime}$-sialyl- $N$-lactosamine and $6^{\prime}$-sialyl- $N$-lactosamine, were unable to bind to VEGFR-2 or suppress their activation, despite the only difference being a single glycan unit, glucose, and $N$-acetylglucosamine [108]. Moreover, our data unraveled that $6^{\prime}$-sialylgalactose is a minimal component that harbors superior binding affinity to VEGFR-2 and suppresses its activation [110]. We also found a potent mechanism that sialyllactose and sialylgalactose might interfere with the interaction between VEGF-A and the immunoglobulin-like domain 2 of VEGFR-2. Binding affinity of free oligosaccharides to VEGFR-2 measured by surface plasmin resonance was relatively lower than that of VEGFA to VEGFR-2 [110,111]. Among the free sialylated oligosaccharides, 6 -sialylgalactose possesses a higher binding affinity than other oligosaccharides [110].

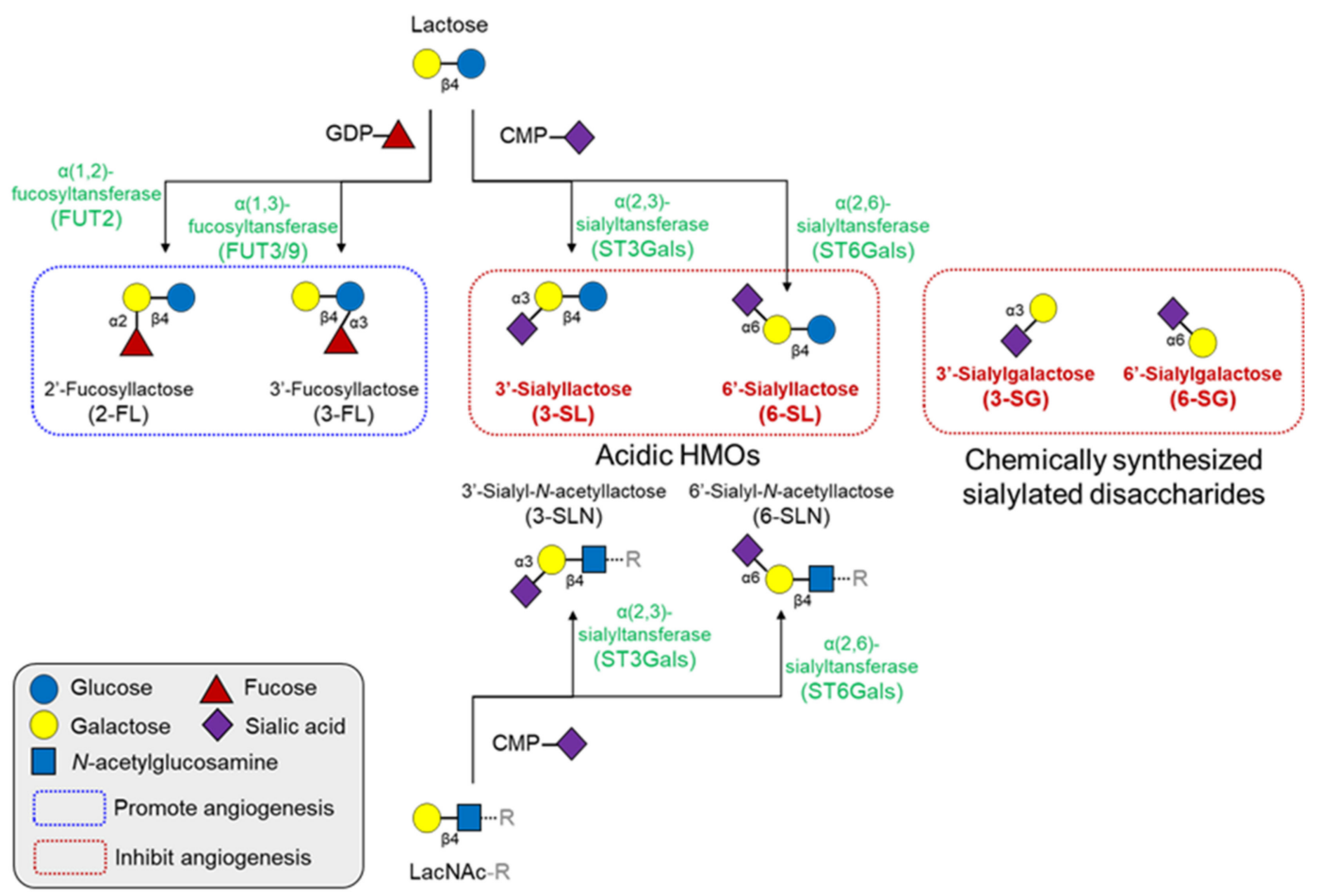

Figure 4. Structures and synthetic pathways of major HMOs and their effects on angiogenesis. All HMOs consist of a lactose core or LacNAc core, with a few exceptions. These cores can be enzymatically elongated in repeats of LacNAc. The elongated HMO chains can be further decorated with fucosylation or sialylation by fucosyltransferases or sialyltransferases, respectively. Fucosylated HMOs generally promotes angiogenesis, but several sialyllactose analogs inhibit angiogenesis. CMP, cytidine monophosphate; GDP, guanosine diphosphate; HMO, human milk oligosaccharides; LacNAc, $N$-acetyllactosamine.

Following VEGFR-2 inhibition by sialylated oligosaccharides, the downstream signaling molecules, including ERK, Akt and p-38, were also suppressed (Figure 5) $[108,110]$. Furthermore, administration of sialylated oligosaccharides sufficiently inhibited angiogenesis in allograft cancer, benign prostate hyperplasia, and premature retinopathy models [108-110]. 


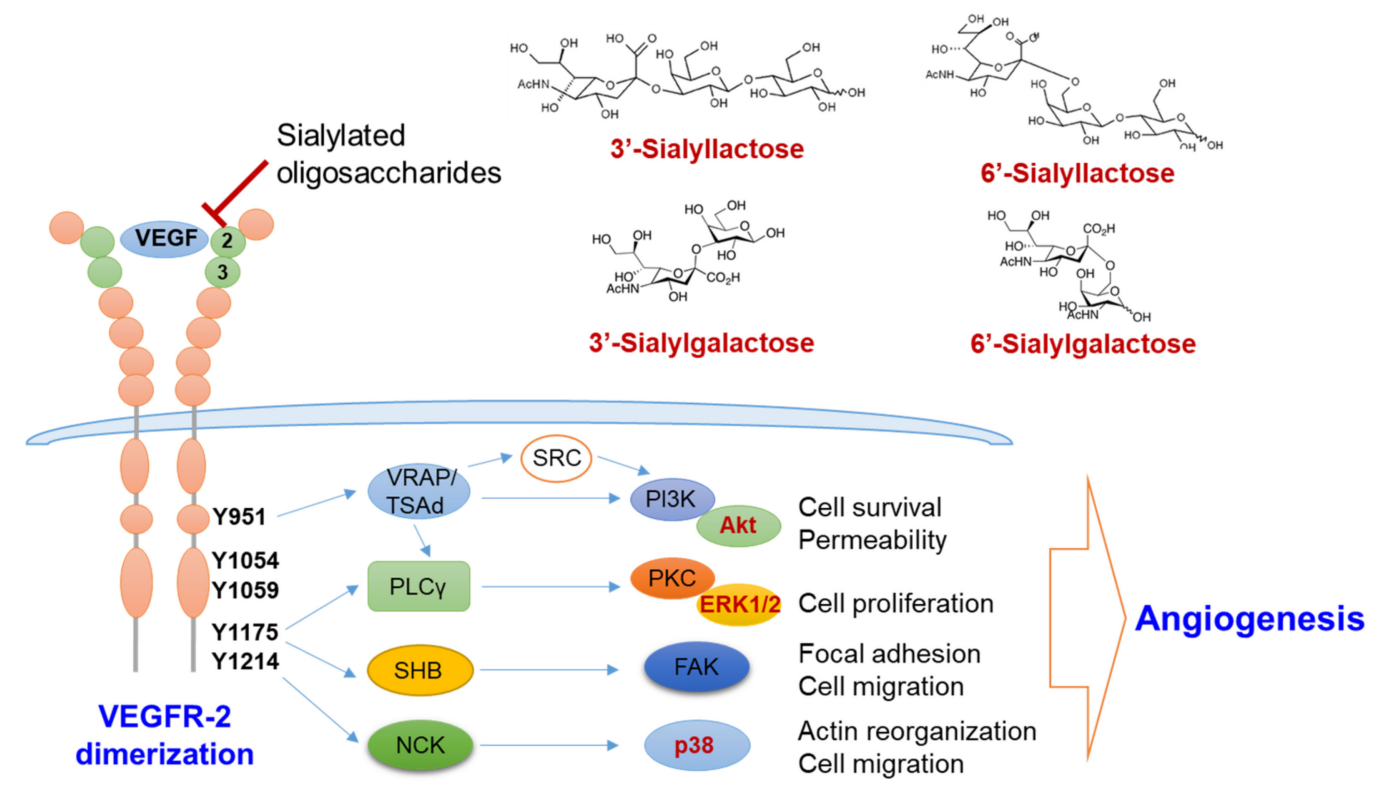

Figure 5. Molecular mechanism of the anti-angiogenic action by sialic acid-containing oligosaccharides. Sialylated lactose and sialylgalactose with sialic acid linked $\alpha 2-3$ or $\alpha 2-6$ to galactose inhibit the activation of VEGFR-2 by interfering the binding between VEGF and VEGFR-2 via Ig-like domain 2 and 3 (green circle). Inhibition of VEGFR-2 activation thereby suppresses the downstream angiogenic signaling pathways, such as the PI3K/Akt, PKC/ERK1/2 and p38 pathways. ERK1/2, extracellular signaling-regulated kinases 1/2; FAK, focal adhesion kinase; NCK, non-catalytic region of tyrosine kinase; PI3K, phosphoinositide 3-kinase; PLC $\gamma$, phospholipase $\gamma$; PKC, protein kinase C; SHB, SH2 domain-containing adapter protein B; TSAd, T-cell specific adaptor protein; VEGF, vascular endothelial cell growth factor; VEGFR, vascular endothelial cell growth factor receptor; VRAP, VEGF-receptor activated protein.

As described above, antibody- and recombinant protein-based drugs are superior to small molecules, such as oligosaccharides, in terms of target specificity. However, their clinical application might be limited due to the high cost, the risk of immunogenicity following long-term treatment, and limited accessibility to target pathological foci owing to their large size $[110,112]$. Natural sialylated HMOs reportedly possess several valuable properties, including low molecular weight, low immunogenicity, and high accessibility to therapeutic targets. Moreover, the safety of $3^{\prime}$ - and $6^{\prime}$-sialyllactoses has previously been confirmed for use in infants as well as in the general population, based on rodent and porcine models [113-115]. Therefore, these in vivo efficacy and safety assessment studies potentiate sialylated oligosaccharides as an anti-angiogenic agent via suppressing the VEGF-A/VEGFR-2 axis. However, to develop sialylated HMOs as clinically available VEGFR-2 inhibitors, further extensive preclinical studies using animal models of pathological angiogenesis, as well as clinical trials, should be warranted. Moreover, identifying superior oligosaccharide analogs with higher binding affinities might help guarantee improved anti-angiogenic effects.

\section{Conclusions}

In the present review, we highlighted the emerging role of sialic acid-containing HMOs in the suppression of VEGFR-2-mediated angiogenesis. Disparately from other glycans contained in HMOs, sialyllactose, and sialylgalactose could inhibit the activation of VEGFR-2 by binding to its immunoglobulin-like domain 2. Although the anti-angiogenic effects of sialylated HMOs have been evaluated in limited in vivo models, such as several cancers, premature retinopathy, and benign prostate hyperplasia, their anti-angiogenic efficacy still has the potential to cure other pathological conditions associated with excessive angiogenesis. Moreover, extensive clinical trials using sialylated oligosaccharides would lead us to new and novel strategies to develop clinically available VEGFR-2 inhibitors from sialylated HMOs. 
Author Contributions: Conceptualization, Y.J.K. and K.-T.H.; methodology, B.B., H.K. and H.P.; formal analysis, B.B., H.K. and K.-T.H.; Data curation, S.-J.B. and K.-T.H.; writing-original draft preparation, B.B. and H.K.; writing-review and editing, S.-J.B. and K.-T.H.; supervision, S.-J.B. and K.-T.H.; funding acquisition, K.-T.H. All authors have read and agreed to the published version of the manuscript.

Funding: This work was supported by the National Research Foundation of Korea (NRF) grants funded by the Korea government (Ministry of Science and ICT, MSIT; 2020R1C1C1003703 to Sung-Jin Bae and 2019R1A2C2003624 to Ki-Tae Ha).

Institutional Review Board Statement: Not applicable.

Informed Consent Statement: Not applicable.

Data Availability Statement: The data presented in this study are openly available.

Acknowledgments: Not applicable.

Conflicts of Interest: The authors declare no conflict of interest.

\section{References}

1. Hill, D.R.; Newburg, D.S. Clinical applications of bioactive milk components. Nutr. Rev. 2015, 73, 463-476. [CrossRef] [PubMed]

2. Ballard, O.; Morrow, A.L. Human milk composition: Nutrients and bioactive factors. Pediatr. Clin. N. Am. 2013, 60, 49-74. [CrossRef]

3. Andreas, N.J.; Kampmann, B.; Mehring Le-Doare, K. Human breast milk: A review on its composition and bioactivity. Early Hum. Dev. 2015, 91, 629-635. [CrossRef] [PubMed]

4. Bode, L. Human milk oligosaccharides: Every baby needs a sugar mama. Glycobiology 2012, 22, 1147-1162. [CrossRef] [PubMed]

5. Thurl, S.; Munzert, M.; Boehm, G.; Matthews, C.; Stahl, B. Systematic review of the concentrations of oligosaccharides in human milk. Nutr. Rev. 2017, 75, 920-933. [CrossRef] [PubMed]

6. Smilowitz, J.T.; Lebrilla, C.B.; Mills, D.A.; German, J.B.; Freeman, S.L. Breast milk oligosaccharides: Structure-function relationships in the neonate. Annu. Rev. Nutr. 2014, 34, 143-169. [CrossRef]

7. Westerbeek, E.A.; Hensgens, R.L.; Mihatsch, W.A.; Boehm, G.; Lafeber, H.N.; van Elburg, R.M. The effect of neutral and acidic oligosaccharides on stool viscosity, stool frequency and stool ph in preterm infants. Acta Paediatr. 2011, 100, 1426-1431. [CrossRef] [PubMed]

8. Westerbeek, E.A.; Morch, E.; Lafeber, H.N.; Fetter, W.P.; Twisk, J.W.; Van Elburg, R.M. Effect of neutral and acidic oligosaccharides on fecal il-8 and fecal calprotectin in preterm infants. Pediatr. Res. 2011, 69, 255-258. [CrossRef]

9. Shimada, I.; Shoji, M.; Futatsuya, R.; Katoh, T.; Kominato, Y.; Sakamoto, T.; Fujikura, T. Elevation of ratio of urinary nacetylneuraminlactose to free sialic acid in some advanced cancer patients. J. Gastroenterol. 1995, 30, 21-27. [CrossRef]

10. Ekman, B.; Wahlberg, J.; Landberg, E. Urine oligosaccharide pattern in patients with hyperprolactinaemia. Glycoconj. J. 2015, 32, 635-641. [CrossRef]

11. Fu, D.; Zopf, D. Analysis of sialyllactoses in blood and urine by high-performance liquid chromatography. Anal. Biochem. 1999, 269, 113-123. [CrossRef] [PubMed]

12. Bode, L.; Kunz, C.; Muhly-Reinholz, M.; Mayer, K.; Seeger, W.; Rudloff, S. Inhibition of monocyte, lymphocyte, and neutrophil adhesion to endothelial cells by human milk oligosaccharides. Thromb. Haemost. 2004, 92, 1402-1410. [CrossRef] [PubMed]

13. Idota, T.; Kawakami, H.; Murakami, Y.; Sugawara, M. Inhibition of cholera toxin by human milk fractions and sialyllactose. Biosci. Biotechnol. Biochem. 1995, 59, 417-419. [CrossRef] [PubMed]

14. Matsubara, T.; Sumi, M.; Kubota, H.; Taki, T.; Okahata, Y.; Sato, T. Inhibition of influenza virus infections by sialylgalactose-binding peptides selected from a phage library. J. Med. Chem. 2009, 52, 4247-4256. [CrossRef]

15. Wang, B. Sialic acid is an essential nutrient for brain development and cognition. Annu. Rev. Nutr. 2009, 29, 177-222. [CrossRef]

16. Wang, B. Molecular mechanism underlying sialic acid as an essential nutrient for brain development and cognition. Adv. Nutr. 2012, 3, 465S-472S. [CrossRef]

17. Potente, M.; Makinen, T. Vascular heterogeneity and specialization in development and disease. Nat. Rev. Mol. Cell Biol. 2017, 18, 477-494. [CrossRef]

18. Monahan-Earley, R.; Dvorak, A.M.; Aird, W.C. Evolutionary origins of the blood vascular system and endothelium. J. Thromb. Haemost. 2013, 11 (Suppl. 1), 46-66. [CrossRef]

19. Flamme, I.; Frolich, T.; Risau, W. Molecular mechanisms of vasculogenesis and embryonic angiogenesis. J. Cell Physiol. 1997, 173, 206-210. [CrossRef]

20. Bikfalvi, A. History and conceptual developments in vascular biology and angiogenesis research: A personal view. Angiogenesis 2017, 20, 463-478. [CrossRef]

21. Fraser, H.M.; Lunn, S.F. Angiogenesis and its control in the female reproductive system. Br. Med. Bull. 2000, 56, 787-797. [CrossRef]

22. Potente, M.; Gerhardt, H.; Carmeliet, P. Basic and therapeutic aspects of angiogenesis. Cell 2011, 146, 873-887. [CrossRef] 
23. Ferrara, N.; Kerbel, R.S. Angiogenesis as a therapeutic target. Nature 2005, 438, 967-974. [CrossRef]

24. Folkman, J. Tumor angiogenesis: Therapeutic implications. N. Engl. J. Med. 1971, 285, 1182-1186.

25. Chung, A.S.; Ferrara, N. Developmental and pathological angiogenesis. Annu. Rev. Cell Dev. Biol. 2011, 27, 563-584. [CrossRef]

26. Carmeliet, P. Angiogenesis in life, disease and medicine. Nature 2005, 438, 932-936. [CrossRef]

27. Polverini, P.J. Angiogenesis in health and disease: Insights into basic mechanisms and therapeutic opportunities. J. Dent. Educ. 2002, 66, 962-975. [CrossRef]

28. Memis, A.; Ozden, C.; Ozdal, O.L.; Guzel, O.; Han, O.; Seckin, S. Effect of finasteride treatment on suburethral prostatic microvessel density in patients with hematuria related to benign prostate hyperplasia. Urol. Int. 2008, 80, 177-180. [CrossRef]

29. De Falco, S. Antiangiogenesis therapy: An update after the first decade. Korean J. Intern. Med. 2014, 29, 1-11. [CrossRef]

30. Betz, C.; Lenard, A.; Belting, H.G.; Affolter, M. Cell behaviors and dynamics during angiogenesis. Development 2016, 143, 2249-2260. [CrossRef]

31. Sweeney, M.; Foldes, G. It takes two: Endothelial-perivascular cell cross-talk in vascular development and disease. Front. Cardiovasc. Med. 2018, 5, 154. [CrossRef] [PubMed]

32. Betsholtz, C. Cell-cell signaling in blood vessel development and function. EMBO Mol. Med. 2018, 10, e8610. [CrossRef] [PubMed]

33. Eelen, G.; Treps, L.; Li, X.; Carmeliet, P. Basic and therapeutic aspects of angiogenesis updated. Circ. Res. 2020, 127, 310-329. [CrossRef] [PubMed]

34. Apte, R.S.; Chen, D.S.; Ferrara, N. Vegf in signaling and disease: Beyond discovery and development. Cell 2019, 176, 1248-1264. [CrossRef]

35. Zirlik, K.; Duyster, J. Anti-angiogenics: Current situation and future perspectives. Oncol. Res. Treat. 2018, 41, 166-171. [CrossRef]

36. Shaik, F.; Cuthbert, G.A.; Homer-Vanniasinkam, S.; Muench, S.P.; Ponnambalam, S.; Harrison, M.A. Structural basis for vascular endothelial growth factor receptor activation and implications for disease therapy. Biomolecules 2020, 10, 1673. [CrossRef]

37. Park, S.A.; Jeong, M.S.; Ha, K.T.; Jang, S.B. Structure and function of vascular endothelial growth factor and its receptor system. BMB Rep. 2018, 51, 73-78. [CrossRef]

38. Karaman, S.; Leppanen, V.M.; Alitalo, K. Vascular endothelial growth factor signaling in development and disease. Development 2018, 145, dev151019. [CrossRef]

39. Hamada, K.; Oike, Y.; Takakura, N.; Ito, Y.; Jussila, L.; Dumont, D.J.; Alitalo, K.; Suda, T. Vegf-c signaling pathways through vegfr-2 and vegfr-3 in vasculoangiogenesis and hematopoiesis. Blood 2000, 96, 3793-3800. [CrossRef]

40. Hiratsuka, S.; Minowa, O.; Kuno, J.; Noda, T.; Shibuya, M. Flt-1 lacking the tyrosine kinase domain is sufficient for normal development and angiogenesis in mice. Proc. Natl. Acad. Sci. USA 1998, 95, 9349-9354. [CrossRef]

41. Michaelsen, S.R.; Staberg, M.; Pedersen, H.; Jensen, K.E.; Majewski, W.; Broholm, H.; Nedergaard, M.K.; Meulengracht, C.; Urup, T.; Villingshoj, M.; et al. Vegf-c sustains vegfr2 activation under bevacizumab therapy and promotes glioblastoma maintenance. Neuro Oncol. 2018, 20, 1462-1474. [CrossRef]

42. Shibuya, M.; Claesson-Welsh, L. Signal transduction by vegf receptors in regulation of angiogenesis and lymphangiogenesis. Exp. Cell Res. 2006, 312, 549-560. [CrossRef]

43. Goldman, J.; Rutkowski, J.M.; Shields, J.D.; Pasquier, M.C.; Cui, Y.; Schmokel, H.G.; Willey, S.; Hicklin, D.J.; Pytowski, B.; Swartz, M.A. Cooperative and redundant roles of vegfr-2 and vegfr-3 signaling in adult lymphangiogenesis. FASEB J. 2007, 21, 1003-1012. [CrossRef]

44. Abhinand, C.S.; Raju, R.; Soumya, S.J.; Arya, P.S.; Sudhakaran, P.R. Vegf-a/vegfr2 signaling network in endothelial cells relevant to angiogenesis. J. Cell Commun. Signal. 2016, 10, 347-354. [CrossRef]

45. Ferrara, N.; Adamis, A.P. Ten years of anti-vascular endothelial growth factor therapy. Nat. Rev. Drug Discov. 2016, 15, 385-403. [CrossRef]

46. Grothey, A.; Galanis, E. Targeting angiogenesis: Progress with anti-vegf treatment with large molecules. Nat. Rev. Clin. Oncol. 2009, 6, 507-518. [CrossRef]

47. Hsu, J.Y.; Wakelee, H.A. Monoclonal antibodies targeting vascular endothelial growth factor: Current status and future challenges in cancer therapy. BioDrugs 2009, 23, 289-304. [CrossRef]

48. Solomon, S.D.; Lindsley, K.; Vedula, S.S.; Krzystolik, M.G.; Hawkins, B.S. Anti-vascular endothelial growth factor for neovascular age-related macular degeneration. Cochrane Database Syst. Rev. 2019, 3, CD005139. [CrossRef]

49. Gramatzki, D.; Roth, P.; Rushing, E.J.; Weller, J.; Andratschke, N.; Hofer, S.; Korol, D.; Regli, L.; Pangalu, A.; Pless, M.; et al. Bevacizumab may improve quality of life, but not overall survival in glioblastoma: An epidemiological study. Ann. Oncol. 2018, 29, 1431-1436. [CrossRef]

50. Kurkjian, C.; Kim, E.S. Risks and benefits with bevacizumab: Evidence and clinical implications. Ther. Adv. Drug Saf. 2012, 3, 59-69. [CrossRef]

51. Ribatti, D.; Annese, T.; Ruggieri, S.; Tamma, R.; Crivellato, E. Limitations of anti-angiogenic treatment of tumors. Transl. Oncol. 2019, 12, 981-986. [CrossRef]

52. Rampogu, S.; Baek, A.; Park, C.; Son, M.; Parate, S.; Parameswaran, S.; Park, Y.; Shaik, B.; Kim, J.H.; Park, S.J.; et al. Discovery of small molecules that target vascular endothelial growth factor receptor-2 signalling pathway employing molecular modelling studies. Cells 2019, 8, 269. [CrossRef] [PubMed]

53. Haibe, Y.; Kreidieh, M.; El Hajj, H.; Khalifeh, I.; Mukherji, D.; Temraz, S.; Shamseddine, A. Resistance mechanisms to antiangiogenic therapies in cancer. Front. Oncol. 2020, 10, 221. [CrossRef] [PubMed] 
54. Yu, J.; Rupasinghe, C.; Wilson, J.L.; Taylor, L.; Rahimi, N.; Mierke, D.; Polgar, P. Targeting receptor tyrosine kinases and their downstream signaling with cell-penetrating peptides in human pulmonary artery smooth muscle and endothelial cells. Chem. Biol. Drug Des. 2015, 85, 586-597. [CrossRef] [PubMed]

55. Davis, M.I.; Hunt, J.P.; Herrgard, S.; Ciceri, P.; Wodicka, L.M.; Pallares, G.; Hocker, M.; Treiber, D.K.; Zarrinkar, P.P. Comprehensive analysis of kinase inhibitor selectivity. Nat. Biotechnol. 2011, 29, 1046-1051. [CrossRef] [PubMed]

56. Michaloski, J.S.; Redondo, A.R.; Magalhaes, L.S.; Cambui, C.C.; Giordano, R.J. Discovery of pan-vegf inhibitory peptides directed to the extracellular ligand-binding domains of the vegf receptors. Sci. Adv. 2016, 2, e1600611. [CrossRef] [PubMed]

57. Sun, J.Z.; Blaskovich, M.A.; Jain, R.K.; Delarue, F.; Paris, D.; Brem, S.; Wotoczek-Obadia, M.; Lin, Q.; Coppola, D.; Choi, K.H.; et al. Blocking angiogenesis and tumorigenesis with gfa-116, a synthetic molecule that inhibits binding of vascular endothelial growth factor to its receptor. Cancer Res. 2004, 64, 3586-3592. [CrossRef]

58. Zilberberg, L.; Shinkaruk, S.; Lequin, O.; Rousseau, B.; Hagedorn, M.; Costa, F.; Caronzolo, D.; Balke, M.; Canron, X.; Convert, O.; et al. Structure and inhibitory effects on angiogenesis and tumor development of a new vascular endothelial growth inhibitor. $J$. Biol. Chem. 2003, 278, 35564-35573. [CrossRef]

59. Furukawa, J.; Fujitani, N.; Shinohara, Y. Recent advances in cellular glycomic analyses. Biomolecules 2013, 3, 198-225. [CrossRef]

60. Stowell, S.R.; Ju, T.; Cummings, R.D. Protein glycosylation in cancer. Annu. Rev. Pathol. 2015, 10, 473-510. [CrossRef]

61. Reily, C.; Stewart, T.J.; Renfrow, M.B.; Novak, J. Glycosylation in health and disease. Nat. Rev. Nephrol. 2019, 15, 346-366. [CrossRef]

62. Ferreira, I.G.; Pucci, M.; Venturi, G.; Malagolini, N.; Chiricolo, M.; Dall'Olio, F. Glycosylation as a main regulator of growth and death factor receptors signaling. Int. J. Mol. Sci. 2018, 19, 580.

63. Goth, C.K.; Petaja-Repo, U.E.; Rosenkilde, M.M. G protein-coupled receptors in the sweet spot: Glycosylation and other post-translational modifications. ACS Pharmacol. Transl. Sci. 2020, 3, 237-245. [CrossRef] [PubMed]

64. Chandler, K.B.; Leon, D.R.; Meyer, R.D.; Rahimi, N.; Costello, C.E. Site-specific n-glycosylation of endothelial cell receptor tyrosine kinase vegfr-2. J. Proteome Res. 2017, 16, 677-688. [CrossRef]

65. Duchesne, L.; Tissot, B.; Rudd, T.R.; Dell, A.; Fernig, D.G. N-glycosylation of fibroblast growth factor receptor 1 regulates ligand and heparan sulfate co-receptor binding. J. Biol. Chem. 2006, 281, 27178-27189. [CrossRef]

66. Kaszuba, K.; Grzybek, M.; Simons, K.; Vattulainen, I.; Coskun, U. N-glycosylation as determinant of epidermal growth factor receptor conformation in membranes. Proc. Natl. Acad. Sci. USA 2015, 112, 4334-4339. [CrossRef]

67. Cui, X.; Xu, H.; Zhou, S.; Zhao, T.; Liu, A.; Guo, X.; Tang, W.; Wang, F. Evaluation of angiogenic activities of hyaluronan oligosaccharides of defined minimum size. Life Sci. 2009, 85, 573-577. [CrossRef]

68. Gao, F.; Cao, M.; Yang, C.; He, Y.; Liu, Y. Preparation and characterization of hyaluronan oligosaccharides for angiogenesis study. J. Biomed. Mater. Res. B Appl. Biomater. 2006, 78, 385-392. [CrossRef]

69. Gao, F.; Liu, Y.; He, Y.; Yang, C.; Wang, Y.; Shi, X.; Wei, G. Hyaluronan oligosaccharides promote excisional wound healing through enhanced angiogenesis. Matrix Biol. 2010, 29, 107-116. [CrossRef]

70. Gao, F.; Yang, C.X.; Mo, W.; Liu, Y.W.; He, Y.Q. Hyaluronan oligosaccharides are potential stimulators to angiogenesis via rhamm mediated signal pathway in wound healing. Clin. Investig. Med. 2008, 31, E106-E116. [CrossRef]

71. Lees, V.C.; Fan, T.P.; West, D.C. Angiogenesis in a delayed revascularization model is accelerated by angiogenic oligosaccharides of hyaluronan. Lab. Investig. 1995, 73, 259-266. [PubMed]

72. Lv, M.; Wang, M.; Cai, W.; Hao, W.; Yuan, P.; Kang, Z. Characterisation of separated end hyaluronan oligosaccharides from leech hyaluronidase and evaluation of angiogenesis. Carbohydr. Polym. 2016, 142, 309-316. [CrossRef]

73. Matou-Nasri, S.; Gaffney, J.; Kumar, S.; Slevin, M. Oligosaccharides of hyaluronan induce angiogenesis through distinct cd44 and rhamm-mediated signalling pathways involving cdc2 and gamma-adducin. Int. J. Oncol. 2009, 35, 761-773.

74. Sattar, A.; Kumar, S.; West, D.C. Does hyaluronan have a role in endothelial cell proliferation of the synovium? Semin. Arthritis Rheum. 1992, 22, 37-43. [CrossRef]

75. Slevin, M.; Kumar, S.; Gaffney, J. Angiogenic oligosaccharides of hyaluronan induce multiple signaling pathways affecting vascular endothelial cell mitogenic and wound healing responses. J. Biol. Chem. 2002, 277, 41046-41059. [CrossRef] [PubMed]

76. Trochon, V.; Mabilat, C.; Bertrand, P.; Legrand, Y.; Smadja-Joffe, F.; Soria, C.; Delpech, B.; Lu, H. Evidence of involvement of cd44 in endothelial cell proliferation, migration and angiogenesis in vitro. Int. J. Cancer 1996, 66, 664-668. [CrossRef]

77. Wang, N.; Liu, C.; Wang, X.; He, T.; Li, L.; Liang, X.; Wang, L.; Song, L.; Wei, Y.; Wu, Q.; et al. Hyaluronic acid oligosaccharides improve myocardial function reconstruction and angiogenesis against myocardial infarction by regulation of macrophages. Theranostics 2019, 9, 1980-1992. [CrossRef] [PubMed]

78. Wang, Y.; Han, G.; Guo, B.; Huang, J. Hyaluronan oligosaccharides promote diabetic wound healing by increasing angiogenesis. Pharmacol. Rep. 2016, 68, 1126-1132. [CrossRef]

79. West, D.C.; Hampson, I.N.; Arnold, F.; Kumar, S. Angiogenesis induced by degradation products of hyaluronic acid. Science 1985, 228, 1324-1326. [CrossRef]

80. West, D.C.; Kumar, S. The effect of hyaluronate and its oligosaccharides on endothelial cell proliferation and monolayer integrity. Exp. Cell Res. 1989, 183, 179-196. [CrossRef]

81. Waterstrat, R.M. New alloys show extraordinary resistance to fracture and wear. J. Am. Dent. Assoc. 1992, 123, 32-36. [CrossRef]

82. Sasisekharan, R.; Ernst, S.; Venkataraman, G. On the regulation of fibroblast growth factor activity by heparin-like glycosaminoglycans. Angiogenesis 1997, 1, 45-54. [CrossRef] 
83. Soker, S.; Svahn, C.M.; Neufeld, G. Vascular endothelial growth factor is inactivated by binding to alpha 2-macroglobulin and the binding is inhibited by heparin. J. Biol. Chem. 1993, 268, 7685-7691. [CrossRef]

84. Maller, S.M.; Cagnoni, A.J.; Bannoud, N.; Sigaut, L.; Perez Saez, J.M.; Pietrasanta, L.I.; Yang, R.Y.; Liu, F.T.; Croci, D.O.; Di Lella, S.; et al. An adipose tissue galectin controls endothelial cell function via preferential recognition of 3-fucosylated glycans. FASEB J. 2020, 34, 735-753. [CrossRef]

85. Tapon-Bretaudiere, J.; Chabut, D.; Zierer, M.; Matou, S.; Helley, D.; Bros, A.; Mourao, P.A.; Fischer, A.M. A fucosylated chondroitin sulfate from echinoderm modulates in vitro fibroblast growth factor 2-dependent angiogenesis. Mol. Cancer Res. 2002, 1, 96-102.

86. Zhu, K.; Amin, M.A.; Zha, Y.; Harlow, L.A.; Koch, A.E. Mechanism by which h-2g, a glucose analog of blood group h antigen, mediates angiogenesis. Blood 2005, 105, 2343-2349. [CrossRef]

87. Zhou, L.; Yin, R.; Gao, N.; Sun, H.; Chen, D.; Cai, Y.; Ren, L.; Yang, L.; Zuo, Z.; Zhang, H.; et al. Oligosaccharides from fucosylated glycosaminoglycan prevent breast cancer metastasis in mice by inhibiting heparanase activity and angiogenesis. Pharmacol. Res. 2021, 166, 105527. [CrossRef]

88. Bandara, M.D.; Stine, K.J.; Demchenko, A.V. The chemical synthesis of human milk oligosaccharides: Lacto-n-tetraose (galbeta1 $\rightarrow$ 3glcnacbeta1 $\rightarrow$ 3galbeta1 $\rightarrow$ 4glc). Carbohydr. Res. 2019, 486, 107824. [CrossRef]

89. Ozcan, E.; Sela, D.A. Inefficient metabolism of the human milk oligosaccharides lacto-n-tetraose and lacto-n-neotetraose shifts bifidobacterium longum subsp. Infantis physiology. Front. Nutr. 2018, 5, 46. [CrossRef]

90. Marcobal, A.; Barboza, M.; Sonnenburg, E.D.; Pudlo, N.; Martens, E.C.; Desai, P.; Lebrilla, C.B.; Weimer, B.C.; Mills, D.A.; German, J.B.; et al. Bacteroides in the infant gut consume milk oligosaccharides via mucus-utilization pathways. Cell Host Microbe 2011, 10, 507-514. [CrossRef]

91. Terrazas, L.I.; Walsh, K.L.; Piskorska, D.; McGuire, E.; Harn, D.A. The schistosome oligosaccharide lacto-n-neotetraose expands gr1(+) cells that secrete anti-inflammatory cytokines and inhibit proliferation of naive cd4(+) cells: A potential mechanism for immune polarization in helminth infections. J. Immunol. 2001, 167, 5294-5303. [CrossRef] [PubMed]

92. Farhadihosseinabadi, B.; Gholipourmalekabadi, M.; Salimi, M.; Abdollahifar, M.A.; Bagheri, M.; Samadikuchaksaraei, A.; Ghanbarian, H.; Mozafari, M.; Kazemi, B.; Niknejad, H. The in vivo effect of lacto-n-neotetraose (lnnt) on the expression of type 2 immune response involved genes in the wound healing process. Sci. Rep. 2020, 10, 997. [CrossRef] [PubMed]

93. Farhadihosseinabadi, B.; Salimi, M.; Kazemi, B.; Samadikuchaksaraei, A.; Ghanbarian, H.; Mozafari, M.; Niknejad, H. Inducing type 2 immune response, induction of angiogenesis, and anti-bacterial and anti-inflammatory properties make lacto-n-neotetraose (lnnt) a therapeutic choice to accelerate the wound healing process. Med. Hypotheses 2020, 134, 109389. [CrossRef] [PubMed]

94. Morrow, A.L.; Ruiz-Palacios, G.M.; Altaye, M.; Jiang, X.; Guerrero, M.L.; Meinzen-Derr, J.K.; Farkas, T.; Chaturvedi, P.; Pickering, L.K.; Newburg, D.S. Human milk oligosaccharides are associated with protection against diarrhea in breast-fed infants. J. Pediatr. 2004, 145, 297-303. [CrossRef] [PubMed]

95. Li, M.; Bai, Y.; Zhou, J.; Huang, W.; Yan, J.; Tao, J.; Fan, Q.; Liu, Y.; Mei, D.; Yan, Q.; et al. Core fucosylation of maternal milk n-glycan evokes b cell activation by selectively promoting the l-fucose metabolism of gut Bifidobacterium spp. and Lactobacillus spp. mBio 2019, 10. [CrossRef]

96. Tsou, P.S.; Ruth, J.H.; Campbell, P.L.; Isozaki, T.; Lee, S.; Marotte, H.; Domino, S.E.; Koch, A.E.; Amin, M.A. A novel role for inducible fut2 in angiogenesis. Angiogenesis 2013, 16, 195-205. [CrossRef]

97. Isozaki, T.; Ruth, J.H.; Amin, M.A.; Campbell, P.L.; Tsou, P.S.; Ha, C.M.; Haines, G.K.; Edhayan, G.; Koch, A.E. Fucosyltransferase 1 mediates angiogenesis, cell adhesion and rheumatoid arthritis synovial tissue fibroblast proliferation. Arthritis Res. Ther. 2014, 16, R28. [CrossRef]

98. Sun, S.; Liu, Z.; Zhou, H.; Li, G.; Liu, M.; Yao, J.; Zhou, T.; An, G.; Wu, Q.; Dong, N. The role of fucosylation in the promotion of endothelial progenitor cells in neovascularization and bone repair. Biomaterials 2014, 35, 3777-3785. [CrossRef]

99. Liu, Y.C.; Yen, H.Y.; Chen, C.Y.; Chen, C.H.; Cheng, P.F.; Juan, Y.H.; Chen, C.H.; Khoo, K.H.; Yu, C.J.; Yang, P.C.; et al. Sialylation and fucosylation of epidermal growth factor receptor suppress its dimerization and activation in lung cancer cells. Proc. Natl. Acad. Sci. USA 2011, 108, 11332-11337. [CrossRef]

100. Yoon, S.J.; Nakayama, K.; Hikita, T.; Handa, K.; Hakomori, S.I. Epidermal growth factor receptor tyrosine kinase is modulated by gm3 interaction with n-linked glcnac termini of the receptor. Proc. Natl. Acad. Sci. USA 2006, 103, 18987-18991. [CrossRef]

101. Hirakawa, M.; Takimoto, R.; Tamura, F.; Yoshida, M.; Ono, M.; Murase, K.; Sato, Y.; Osuga, T.; Sato, T.; Iyama, S.; et al. Fucosylated tgf-beta receptors transduces a signal for epithelial-mesenchymal transition in colorectal cancer cells. Br. J. Cancer 2014, 110, 156-163. [CrossRef]

102. Chandler, K.B.; Leon, D.R.; Kuang, J.; Meyer, R.D.; Rahimi, N.; Costello, C.E. N-glycosylation regulates ligand-dependent activation and signaling of vascular endothelial growth factor receptor 2 (vegfr2). J. Biol. Chem. 2019, 294, 13117-13130. [CrossRef]

103. Chung, T.W.; Kim, S.J.; Choi, H.J.; Kim, K.J.; Kim, M.J.; Kim, S.H.; Lee, H.J.; Ko, J.H.; Lee, Y.C.; Suzuki, A.; et al. Ganglioside gm3 inhibits vegf/vegfr-2-mediated angiogenesis: Direct interaction of gm3 with vegfr-2. Glycobiology 2009, 19, 229-239. [CrossRef]

104. Mukherjee, P.; Faber, A.C.; Shelton, L.M.; Baek, R.C.; Chiles, T.C.; Seyfried, T.N. Thematic review series: Sphingolipids. Ganglioside gm3 suppresses the proangiogenic effects of vascular endothelial growth factor and ganglioside gd1a. J. Lipid Res. 2008, 49, 929-938. [CrossRef]

105. Bousseau, S.; Vergori, L.; Soleti, R.; Lenaers, G.; Martinez, M.C.; Andriantsitohaina, R. Glycosylation as new pharmacological strategies for diseases associated with excessive angiogenesis. Pharmacol. Ther. 2018, 191, 92-122. [CrossRef] 
106. Chiodelli, P.; Urbinati, C.; Paiardi, G.; Monti, E.; Rusnati, M. Sialic acid as a target for the development of novel antiangiogenic strategies. Future Med. Chem. 2018, 10, 2835-2854. [CrossRef]

107. Rudloff, S.; Schneider, D.; Kunz, C.; Bretzel, R.G.; Linn, T. Human milk as a natural source of anti-angiogenic compounds. Pediatr. Res. 2004, 56, 503. [CrossRef]

108. Chung, T.W.; Kim, E.Y.; Kim, S.J.; Choi, H.J.; Jang, S.B.; Kim, K.J.; Ha, S.H.; Abekura, F.; Kwak, C.H.; Kim, C.H.; et al. Sialyllactose suppresses angiogenesis by inhibiting vegfr-2 activation, and tumor progression. Oncotarget 2017, 8, 58152-58162. [CrossRef]

109. Kim, E.Y.; Jin, B.R.; Chung, T.W.; Bae, S.J.; Park, H.; Ryu, D.; Jin, L.; An, H.J.; Ha, K.T. 6-sialyllactose ameliorates dihydrotestosterone-induced benign prostatic hyperplasia through suppressing vegf-mediated angiogenesis. BMB Rep. 2019, 52, 560-565. [CrossRef]

110. Chung, T.W.; Kim, E.Y.; Choi, H.J.; Han, C.W.; Jang, S.B.; Kim, K.J.; Jin, L.; Koh, Y.J.; Ha, K.T. $6^{\prime}$-sialylgalactose inhibits vascular endothelial growth factor receptor 2-mediated angiogenesis. Exp. Mol. Med. 2019, 51, 1-13. [CrossRef]

111. Teran, M.; Nugent, M.A. Characterization of receptor binding kinetics for vascular endothelial growth factor-a using spr. Anal. Biochem. 2019, 564-565, 21-31. [CrossRef] [PubMed]

112. Prueksaritanont, T.; Tang, C. Adme of biologics-what have we learned from small molecules? AAPS J. 2012, 14, 410-419. [CrossRef] [PubMed]

113. Phipps, K.R.; Baldwin, N.J.; Lynch, B.; Stannard, D.R.; Soltesova, A.; Gilby, B.; Miks, M.H.; Rohrig, C.H. Toxicological safety evaluation of the human-identical milk oligosaccharide 6 '-sialyllactose sodium salt. J. Appl. Toxicol. 2019, 39, $1444-1461$. [CrossRef]

114. Phipps, K.R.; Baldwin, N.J.; Lynch, B.; Stannard, D.R.; Soltesova, A.; Gilby, B.; Miks, M.H.; Rohrig, C.H. Toxicological safety assessment of the human-identical milk oligosaccharide 3 '-sialyllactose sodium salt. J. Appl. Toxicol. 2019, 39, 1378-1393. [CrossRef] [PubMed]

115. Monaco, M.H.; Gurung, R.B.; Donovan, S.M. Safety evaluation of 3'-siallylactose sodium salt supplementation on growth and clinical parameters in neonatal piglets. Regul. Toxicol. Pharmacol. 2019, 101, 57-64. [CrossRef] 